Volume 11, Issue 12, December 2020, pp. 247-258. Article ID: IJM_11_12_024

Available online at http://iaeme.com/Home/issue/IJM?Volume $=11 \&$ Issue $=\overline{1} 2$

Journal Impact Factor (2020): 10.1471 (Calculated by GISI) www.jifactor.com

ISSN Print: 0976-6502 and ISSN Online: 0976-6510

DOI: 10.34218/IJM.11.12.2020.024

(C) IAEME Publication

Scopus Indexed

\title{
FINALIZING THE INSTRUMENT ADAPTED TO MEASURE ENTREPRENEURIAL MOTIVATION
}

\author{
Mohd Nor Hakimin Bin Yusoff \\ Faculty of Entrepreneurship and Business, Universiti Malaysia Kelantan, Malaysia \\ Fakhrul Anwar Zainol \\ Faculty of Business and Management, Universiti Sultan Zainal Abidin, Malaysia \\ Tengku Mohd Azizuddin Tuan Mahmood \\ Faculty of Entrepreneurship and Business, Universiti Malaysia Kelantan, Malaysia
}

\begin{abstract}
Abdullah Al Mamun
Global Entrepreneurship Research and Innovation Centre (GERIC),

Universiti Malaysia Kelantan, Malaysia
\end{abstract}

\section{Mohamad Bin Ismail}

Faculty of Entrepreneurship and Business, Universiti Malaysia Kelantan, Malaysia

Asyraf Afthanorhan*

Faculty of Business and Management, Universiti Sultan Zainal Abidin, Malaysia

*Corresponding Author

\begin{abstract}
The objective of this study is to develop and validate an instrument to measure entrepreneurial motivation among the low-income households in Kelantan, Malaysia. The present study attempts to answer the call of existing studies, which reported inadequate entrepreneurship research within developing economies by examining the constructs of Self-Improvement, Self-Confidence, Openness to Change, Pull Factors, and Need for Achievement as components of an instrument to measure Entrepreneurial Motivation. This study adopted a cross-sectional design with quantitative data collected from 800 households in four districts in Kelantan, Malaysia, through a structured interview. Based on the reliability and validity testing, this study finalized the instrument to 25 items yielding five factors, i.e., selfimprovement, self-confidence, openness to change, pull factors, and need for achievement. The findings of the reflective hierarchical model revealed that need for achievement is the highest contributor to entrepreneurial motivation among the lowincome households in Kelantan, Malaysia; followed by self-confidence, pull factors,
\end{abstract}


self-improvement, and openness to change. It is recommended that future researchers continue to develop the instrument by cross-examining the instrument across different income level groups living in both low-income and developed economies.

Key words: Motivation; Self-Improvement; Self-Confidence; Openness to Change; Pull Factors; Need for Achievement.

Cite this Article: Mohd Nor Hakimin B Yusoff, Fakhrul Anwar Zainol, Mohamad B Ismail, Abdullah Al-Mamun, Tengku Md Azizudin Tuan Mahmood, Asyraf Afthanorhan, Finalizing the Instrument Adapted to Measure Entrepreneurial Motivation, International Journal of Management, 11(12), 2020, pp 247-258.

http://iaeme.com/Home/issue/IJM?Volume=11\&Issue=12

\section{INTRODUCTION}

Entrepreneurship could be perceived as various activities associated with owning and managing businesses (Nazri, Aroosha, \& Omar, 2016). Entrepreneurship not only drives innovation and technical transformations, but also generates economic growth (Shane, Locke, \& Collins, 2003). Entrepreneurship is considered to be a significant process by which innovative knowledge is transformed into new services and products thereby equilibrating supply and demand (Shane \& Venkataraman, 2000). According to earlier studies entrepreneurship is a mechanism capable of discovering and mitigating spatial and temporal inefficiencies in an economy (Kirzner, 1997). Moreover, entrepreneurship is also found to play a significant role in the development of intellectual capital and human assets (Zahra \& Dess, 2001; Yusof, W.N.H.S.W., Zainol, F.A., Daud, W.N.W, 2019). Particularly in the context of developing nations, the emergence of entrepreneurs and entrepreneurship has been found to be the most important factor in the success of many emerging economies, such as, Bangladesh, the Maldives, and others (Beaugrand, 2004).

McClelland (1961) explains that the term entrepreneurs, includes both small business owners and other managers with decision-making responsibilities. Such forms of micro or small entrepreneurships are mainly one-person operations, poorly managed, not always permanent, usually less productive, often informal, and undercapitalized (Eijdenberg \& Masurel, 2013) business ventures that have been found to be extensively popular among the low-income and underprivileged communities as a powerful tool for combating poverty and empowering the poor economically (Basargekar, 2011). Moreover, the positive role of small sized enterprises particularly that of new ventures has been widely acknowledged in the development literature, thanks to the crucial role played by micro-enterprises in the socioeconomic development of low-income households along with the support it extends towards maintaining healthy and sustainable economic growth (Al-Mamun, Saufi, \& Ismail, 2016).

Saleh and Ndubisi (2006) and Bin Yusoff, Zainol and Ibrahim (2015), disclosed that small to medium sized enterprises are one of the most significant contributors towards economic development in Malaysia. Moreover, according to recent research, both the informal economy and its tenants, comprised of small and micro-enterprises, have been found to act as engines of economic dynamism in the context of Malaysia; perhaps because of a significant proportion of such underprivileged micro-entrepreneurs operating within the informal economy of the country (Al-Mamun et al., 2016). It is evident that although entrepreneurship among low-income and underprivileged communities is prevalent globally and both the developed and developing nations host informal economies and their enterprises, entrepreneurship remains most beneficial for emerging economies, which is why the policies and programmes of the Malaysian Government, along with other development organizations 
in the country, have been nurturing an entrepreneurship supportive environment to promote entrepreneurial activities among the low-income and underprivileged communities (AlMamun \& Ekpe, 2016).

All human actions, including entrepreneurship, are the result of motivational and cognitive factors embedded within an individual with variations among individuals, in terms of ability and willingness to act, which significantly affecting the entrepreneurial process (Shane et al., 2003). In the context of micro-entrepreneurship, motivation, which is much emphasized among the relevant theoretical models, remains a key element governing the behaviour of entrepreneurs which, thereby, influences the success of small businesses (Robichaud et al., 2001). Entrepreneurial motivation refers to the personal impact of beliefs and the expectation outcomes of venturing into entrepreneurship that significantly affect entrepreneurial intention (Almobaireek \& Manolova, 2012; Nazri et al., 2016). According to Hessels et al. (2008), entrepreneurial motivation plays an important role in understanding entrepreneurial outcomes. Moreover, it is believed that a deeper investigation into the concept of entrepreneurial motivation would lead to a richer understanding of entrepreneurs' behavioural patterns and the impact of such patterns on business performance (Robichaud et al., 2001). Perhaps, this is why a recent study conveyed that growing research attention seems to be converging, in the field of entrepreneurship motivation, within recent streams of research (Eijdenberg \& Masurel, 2013).

A study aimed at developing and validating an instrument for entrepreneurial motivation needs to accept that previous research has quite rightly criticized existing empirical studies on the role of human motivation in entrepreneurship; however, it could be argued that such criticism has resulted with insufficient consideration of the otherwise significant role of motivation noted in the entrepreneurial process in recent entrepreneurship research (Shane et al., 2003). Moreover, acknowledging the well-versed significance of entrepreneurial motivation among relevant theoretical models to predict entrepreneurial behaviour and thereby influence firm performance (Robichaud et al., 2001), the present study feels it is necessary to develop a valid instrument to measure the construct, particularly in the context of entrepreneurship among low-income and underprivileged communities in developing nations, which remains a significant and yet unexplored research area. Therefore, the present study attempts to answer the call of Naude (2010), who reported that research on entrepreneurship, particularly in the context of developing economies remains inadequate.

\section{LITERATURE REVIEW}

\subsection{Entrepreneurial Motivation and its Components}

Almobaireek and Manolova (2012) define entrepreneurial motivation as the beliefs and expectation, of the personal impact of outcomes, when venturing into entrepreneurship. In other words, entrepreneurial motivation could be perceived as goals and objectives that entrepreneurs seek to accomplish by means of business ownership (Robichaud et al., 2001). Empirically, entrepreneurial motivation has been found to be a significant predictor of entrepreneurial intention (Nazri et al., 2016). In the process of reviewing the relevant literature with the objective of conceptualizing a valid measure of entrepreneurial motivation, a list of various attributes emerged, primarily from the much-referenced Shane et al. (2003), including; the need for achievement, an individual's locus of control, vision, desire for independence, passion, goal setting, self-drive, and self-efficacy.

Additionally, Eijdenberg and Masurel (2013) were found to prescribe the "pull" or "push" factors as entrepreneurial motivators; while Levesque, Shepherd, and Douglas (2002) stressed that entrepreneurial motivation depends on an individual's age, and Grilo and Thurik (2008) argued that gender, age, and level of education, influence individuals to engage in 
entrepreneurship. On the other hand, an earlier study indicated that entrepreneurs are motivated by the reward structure of the economy where a new venture focuses on the usefulness, utility, or desirability of an entrepreneurial career (Baumol, 1996). Other researchers mentioned the expected net present economic benefits of entrepreneurship in comparison to the expected gains from wage labour (Campbell, 1992), when a scenario was found where the expected rewards surpassed the wages of employment so that the individual pursued entrepreneurship (Praag \& Cramer, 2001; Majid et al., 2020).

However, as the present study focuses primarily on entrepreneurship among low-income or underprivileged entrepreneurs, it therefore converged and built on the traits or personalities of the entrepreneurs rather than their actions (Renko et al., 2015), as entrepreneurship is exemplified by the characteristics of the entrepreneur (Man, Lau, \& Snape, 2008), particularly among the entrepreneurial organizations where entrepreneurs play the founding and dominant role in terms of business development (Daily et al., 2002). Moreover, the choice of the following entrepreneurial motivational components was also based on the argument that all human actions, including entrepreneurship, are the result of motivational and cognitive factors embedded within an individual, with variation among individuals in terms of ability and willingness to act, which significantly affect the entrepreneurial process (Shane et al., 2003). Therefore, in an effort to develop the constructs, upon which questions could be created to measure entrepreneurial motivation, the present study limited its discussions to the constructs of immediate interest thereby extensively defining self-improvement, self-confidence, openness to change, pull factors, and the need for achievement, as factors of entrepreneurial motivation.

\subsubsection{Self-Improvement}

Barba-Sánchez and Atienza-Sahuquillo (2012) theorised that although an individual's ultimate goal can be achieved without the need to prove anything to anyone; the need for success requires self-improvement. Related research revealed that self-improvement is one of the motivators to initiate a business (Hussain, et al., 2008; Sabiu, I.T., Zainol, F.A., Abdullah, A.A, 2019) Research further disclosed that self-improvement factors such as, higher social position, financial gain, gaining experience, reaching a personal vision, and achievement significantly influence entrepreneurial motivation (Almobaireek \& Manolova, 2012; Baistaman et al., 2020). In the context of measuring the construct, Carter et al. (2003) acknowledged that items such as financial success, self-realization, role models, recognition, innovation, and independence, which are all career motivators for nascent entrepreneurs, could be employed as measures of self-improvement which influence individuals to engage in entrepreneurial activities.

\subsubsection{Self-Confidence}

Self-confidence in the present context refers to an individual's ability to assemble and implement the resources, competencies, and skills necessary for attaining a certain level of achievement in a particular task (Bandura, 1997; Majid et al., 2019). Previous study asserted that task specific self-confidence is a strong predictor of certain dimensions of entrepreneurship, such as general traits, motives, specific skills, competencies, vision, strategic action, and situation-specific motivation (Baum, 1994). Accordingly, Shane et al. (2003) forwarded that people with higher self-efficacy (task specific self-confidence) and optimism are more likely to pursue an entrepreneurial process; even though, situations often remain ambiguous and require constant effort, planning, and persistence in order to proceed. Kiggundu (2002) also acknowledged self-confidence as another significant competency that motivates entrepreneurial activities. Moreover, Eijdenberg and Masurel (2013) conveyed that self-confidence and trust among individuals was expected to stimulate entrepreneurship. 
Furthermore, according to recent research, an individual's entrepreneurial intention is contingent on the desirability of entrepreneurship and the attractiveness of emerging as an entrepreneur, along with a level of self-confidence that the action of entrepreneurship could actually be realized (Nazri et al., 2016).

\subsubsection{Openness to Change}

Openness to Change could be translated as an individual's ability to be open to new ideas, innovation, and independent decisions which have been found to play a significant role in regard to entrepreneurship (Nazri et al., 2016; Zainol et al., 2019). According to research, organizations are entities that confront change on a regular basis while striving to retain their competitive positions (Wanberg \& Banas, 2000). In this context, micro-entrepreneurs, as owners and managers of a firm, constantly need to work beyond fixed job descriptions and thereby manage change by means of reorganizing, downsizing, and implementing innovative technology. Moreover, according to Shane et al. (2003), entrepreneurship is driven by technical and innovative changes, and therefore, is able to generate economic growth, which indicates that the construct of change is a predictor of entrepreneurial motivation. Furthermore, Robichaud et al. (2001) in his study also acknowledged adaptability to change as a significant element when developing an instrument to measure entrepreneurial motivation.

\subsubsection{Pull Factors}

Pull factors refer to the unforced personal desire of individuals which influence them to embark on their own business venture and thereby transform themselves into entrepreneurs (Nazri et al., 2016). Spencer and Spencer (1993) stated that pull factors instigate entrepreneurial motive to select, direct, and drive behaviour towards certain goals or actions. According to research, pull factors are considered positive motivators of entrepreneurship as they attract individuals to become self-employed and thereby significantly predict entrepreneurial motivation (Eijdenberg \& Masurel, 2013; Bahkia et al., 2019). Pull factors or opportunity driven entrepreneurship has been validated in both developed and developing countries' and, according to existing relevant literature, the construct could be measured with the concepts of independence, autonomy, authoring, making declarations, obtaining higher profit rates, increased market size, and access to finance. These indicators of the pull factor significantly influence entrepreneurship motivation (Naude et al., 2008; Rindova et al., 2009; Eijdenberg \& Masurel, 2013).

\subsubsection{Need for Achievement}

While reviewing existing literature, need for achievement has been found to be a much talked about construct pertaining to entrepreneurial motivation. McClelland (1961) argued that individuals with a higher need for achievement are keen to engage in tasks or activities, such as entrepreneurship, that require a high degree of individual responsibility, skill, and effort for desired outcomes which have a moderate degree of risk involved and include clear feedback on performance; in comparison to their counterparts, who possessed a lower need for achievement. Collins, Locke, and Hanges (2000) claimed that need for achievement is significantly associated with founding a company, while according to Johnson (1990), a significant relationship exists between need for achievement and entrepreneurial activities. Mitchell (2004) and Kiggundu (2002) also found need for achievement to be one of the most significant factors that motivate entrepreneurs in underdeveloped nations. Furthermore, according to the recent and prominent Shane et al. (2003) need for achievement is one of the most significant factors that influence entrepreneurial motivation and people with a higher need for achievement are the ones who are more likely to pursue entrepreneurial jobs. 


\section{RESEARCH METHODOLOGY}

This study adopted a cross-sectional approach to develop and validate an instrument to measure entrepreneurial motivation among the low-income households in Kelantan, Malaysia. The target population for this study are the low-income households of the poorest state in Peninsular Malaysia, which is Kelantan. This study then selected four locations in Kelantan which included Bachok, Tumpat, Jeli, and Gua Musang. The population of this study were the low-income households registered under 'Majlis Agama Islam Dan Adat Istiadat Melayu Kelantan (ASNAF)'. A total of 3,090 low-income households formed the population across the four districts, i.e., Bachok (1394), Tumpat (1257), Jeli (233), and Gua Musang (206). Since this study intends to compare across locations and other anticendents, it randomly selected 800 low-income respondents with a total of 200 respondents from each location. Data was collected through face-to-face structured interviews.

\subsection{Research Instrument}

The questionnaire was translated into Malay and checked for inter-translator consistency. The questionnaire was developed based on a review of the existing entrepreneurship indices and tested through a pilot survey, after which, the instrument was enhanced based on the comment and feedback from the pilot survey. This study used a five-point Likert scale ranging from one which denoted "strongly disagree" to five which denoted "strongly agree" to avoid confusion and biases of fatigue on longer scales. The research instrument was adapted and modified from past studies and the existing entrepreneurship index (i.e., Norasmah et al., 2006; Noraishah, 2003). Table 1 below shows the questions adopted on the research instrument for this study.

Table 1 Research Instrument - Entrepreneurial Motivation

\begin{tabular}{ll}
\hline Code & \\
\hline B164 & I have a better sense of personal feelings \\
B165 & I have a positive attitude toward others feelings \\
B166 & A person is different in different types of situations than others \\
B167 & Ability to prepare and implement business plans \\
B168 & Persistence when faced with tasks that are unpleasant \\
B169 & If not successful with the previous task, I will perform a new task \\
B170 & Difficulties in making decisions about important matters \\
B171 & I am quickly discouraged when faced with problems \\
B172 & When I was educated in something, the more the idea of business opportunities arose \\
B173 & When I am not sure about something, I'll find someone who can help with all the business problems \\
B174 & I am confident of my abilities and feel good about myself \\
B175 & I feel self-confident when I am with very successful business people \\
B176 & I frequently have doubts about myself of my abilities when making business proposals \\
B177 & I worry about what my business associates think of me \\
B178 & Good knowledge when dealing with others creates further business opportunities \\
B179 & My profession helps me to achieve my goals in life \\
B180 & I get along well with my superiors at work \\
B181 & The feedback I get from my co-workers helps me to improve my work \\
B182 & I only do this job so that I get paid at the end of the month \\
B183 & After a day off I have new energy to work hard again \\
B184 & At work I do things that need doing without being told \\
B185 & This job gives me a feeling of achievement and accomplishment \\
B189 & I want others to appreciates what I have done \\
B190 & Being very successful is important to me \\
B191 & I like to get others' attention \\
B192 & I thinks it is important to be highly ambitious \\
B193 & I want to show the extent of my capability \\
B194 & Getting ahead in life is important to me \\
B195 & I strive to do better than others \\
\hline
\end{tabular}




\section{SUMMARY OF FINDINGS}

\subsection{Demographic Characteristics}

For the purpose of the present study, four cities from the state of Kelantan, Malaysia were selected, i.e., Bachok, Tumpat, Jeli, and Gua Musang. The survey was conducted with a total of 800 respondents, of which, most were female totaling 544 respondents $(68.0 \%)$ and the rest were male totaling 256 respondents $(32.0 \%)$. The age groups were divided into four tiers, of which; the first tier consisted of 81 respondents $(10.1 \%)$ who were less than 31 years old, the second tier consisted of 250 respondents $(31.3 \%)$ who represented the ages between $31-45$ years old, the third tier consisted of 177 respondents $(22.1 \%)$ who reflected the age group between 46-55 years old, and the last and final tier consisted of 292 respondents $(36.5 \%)$ who accounted for the age group of those "over 55 years old". The respondents were also asked about the number of children they had which were again grouped into five categories, of which, most of the respondents reported to have 4-6 children with $37.1 \%$ (297 respondents), $34 \%$ or 272 respondents reported to have less than four children, $14.6 \%$ or 117 reported having 7-9 children, $3.9 \%$ or 31 respondents reported having $10-12$ children, $0.6 \%$ or 5 respondents reported having more than 12 children, and $9.8 \%$ or 78 respondents said they did not have any children.

Furthermore, the survey also recorded the respondents' interest pertaining to venturing into business. In their responses, $71.3 \%$ of the respondents agreed they had an interest in starting a business while $25.3 \%$ denied having an interest in a new business, and the rest at $3.5 \%$ reported that they were not sure about whether they wanted to be involved in business. The respondents were also asked whether they had any previous business experience. In this case, the respondents were categorized according to their years of business experience, of which, $30.1 \%$ of the respondents claimed to be associated with "less than five years of experience", $10.4 \%$ respondents reported to have between 6 and 10 years of experience, $4.4 \%$ of the respondents had between 11 and 15 years of experience, $2.8 \%$ of the respondents reported having 16 to 20 years of experience, while $5.3 \%$ of the respondents allegedly had more than 21 years of previous business experience. However, a large portion of about $47.1 \%$ of the respondents reported not having any previous business experience at all.

\subsection{Measuring Validity}

The Fornell-Larcker criterion postulates that latent variables are expected to share more variance with their assigned indicators than with any other latent variable, therefore the AVE of each latent variable should be greater than the latent variable's highest squared correlation to any other latent variable (Henseler, Ringle, \& Sinkovics, 2009; Mohamad et al., 2019). As observed in Table 2, all constructs, except for "need for achievement" and "self-efficacy", meet the set criteria. However, since the AVE values as noted in Table 4 are higher than 0.5 and almost all loadings of each indicator are found to be greater than all of its cross-loadings (Table 3), this study concluded that there is no evidence of a lack of discriminant validity.

Table 2 Validity

\begin{tabular}{|c|c|c|c|c|c|c|}
\hline & $\begin{array}{c}\text { Self- } \\
\text { Improvement }\end{array}$ & $\begin{array}{c}\text { Self- } \\
\text { Confidence }\end{array}$ & $\begin{array}{l}\text { Openness } \\
\text { to Change }\end{array}$ & $\begin{array}{c}\text { Pull } \\
\text { Factors }\end{array}$ & $\begin{array}{c}\text { Need for } \\
\text { Achievement }\end{array}$ & $\begin{array}{c}\text { Entrepreneurial } \\
\text { Motivation }\end{array}$ \\
\hline \multicolumn{7}{|c|}{ Fornell-Larcker Criterion } \\
\hline Self-Improvement & 0.818 & & & & & \\
\hline Self-Confidence & 0.754 & 0.760 & & & & \\
\hline Openness to Change & 0.483 & 0.700 & 0.886 & & & \\
\hline Pull Factors & 0.581 & 0.747 & 0.852 & 0.920 & & \\
\hline Need for Achievement & 0.760 & 0.884 & 0.637 & 0.723 & 0.849 & \\
\hline $\begin{array}{l}\text { Entrepreneurial } \\
\text { Motivation }\end{array}$ & 0.816 & 0.955 & 0.787 & 0.851 & 0.947 & 0.742 \\
\hline
\end{tabular}




\subsection{Demographic, Reliability, and Validity}

The mean and standard deviation values, as represented in Table 4, indicate that the values in the statistical data set of the present study are relatively close to the mean of the entire data set used for the present study. However, in order to achieve robust research, reliable and valid items are required. The first criterion for such an evaluation is typically the internal consistency reliability. Cronbach's alpha presumes that all the used indicators are equally reliable (Hair et al., 2013; Afthanorhan et al., 2020). For this study, the reliability of the data is shown in Table 4 below, based on the Cronbach's alpha, composite reliability, and the Average Variance Extracted (AVE). The Cronbach's alpha for Self-Improvement, SelfConfidence, Openness to Change, Pull Factors, Need for Achievement, and Entrepreneurial Motivation have all been found to be more than 0.7, thus, all the items used for the present study could be considered reliable.

Table 3 Cross Loading

\begin{tabular}{ccccccc}
\hline & $\begin{array}{r}\text { Self- } \\
\text { Improvemen } \\
\text { t }\end{array}$ & $\begin{array}{c}\text { Self- } \\
\text { Confidence }\end{array}$ & $\begin{array}{c}\text { Openness to } \\
\text { Change }\end{array}$ & Pull Factors & $\begin{array}{r}\text { Need for } \\
\text { Achievement }\end{array}$ & $\begin{array}{r}\text { Entrepreneuri } \\
\text { al Motivation }\end{array}$ \\
\hline B164 & 0.864 & 0.566 & 0.383 & 0.456 & 0.590 & 0.643 \\
B165 & 0.871 & 0.562 & 0.369 & 0.457 & 0.588 & 0.640 \\
B166 & 0.827 & 0.574 & 0.353 & 0.449 & 0.595 & 0.637 \\
B167 & 0.697 & 0.728 & 0.456 & 0.517 & 0.685 & 0.721 \\
B168 & 0.688 & 0.822 & 0.474 & 0.543 & 0.773 & 0.787 \\
B169 & 0.634 & 0.824 & 0.567 & 0.618 & 0.751 & 0.796 \\
B172 & 0.560 & 0.806 & 0.457 & 0.522 & 0.706 & 0.733 \\
B173 & 0.534 & 0.630 & 0.391 & 0.427 & 0.537 & 0.590 \\
B174 & 0.507 & 0.520 & 0.313 & 0.341 & 0.423 & 0.487 \\
B175 & 0.592 & 0.797 & 0.551 & 0.600 & 0.704 & 0.759 \\
B178 & 0.519 & 0.820 & 0.624 & 0.606 & 0.707 & 0.767 \\
B179 & 0.557 & 0.801 & 0.793 & 0.796 & 0.702 & 0.818 \\
B180 & 0.495 & 0.693 & 0.930 & 0.797 & 0.632 & 0.767 \\
B181 & 0.500 & 0.705 & 0.945 & 0.818 & 0.651 & 0.784 \\
B182 & 0.233 & 0.408 & 0.772 & 0.629 & 0.351 & 0.490 \\
B183 & 0.515 & 0.676 & 0.768 & 0.913 & 0.636 & 0.763 \\
B184 & 0.539 & 0.686 & 0.796 & 0.926 & 0.676 & 0.790 \\
B185 & 0.548 & 0.699 & 0.787 & 0.922 & 0.683 & 0.796 \\
B189 & 0.552 & 0.646 & 0.629 & 0.637 & 0.745 & 0.735 \\
B190 & 0.633 & 0.775 & 0.603 & 0.643 & 0.866 & 0.829 \\
B191 & 0.638 & 0.800 & 0.530 & 0.622 & 0.877 & 0.828 \\
B192 & 0.681 & 0.644 & 0.389 & 0.501 & 0.753 & 0.704 \\
B193 & 0.674 & 0.798 & 0.544 & 0.637 & 0.908 & 0.848 \\
B194 & 0.689 & 0.813 & 0.584 & 0.657 & 0.903 & 0.862 \\
B195 & 0.654 & 0.760 & 0.497 & 0.593 & 0.874 & 0.808 \\
\hline & & & & & & \\
& & & & & \\
\end{tabular}

Moreover, according to Hair et al. (2013), the reliability value of an item, particularly for composite reliability values of 0.7 and more, are acceptable, which is the case for the present study (see Table 4), indicating that all items in the present study could be considered acceptable. As for the Average Variance Extracted (AVE), Hair et al. (2011) stated that the values should be higher than 0.50 because, if the AVE is less than 0.50 on average, more error remains in the items than the variance that is explained by the construct (Hair et al., 2013). In Table 4, the AVE values for all the variables are found to be higher than 0.50 , which indicates an acceptable convergent validity.

On the other hand, one procedure for assessing discriminant validity is by examining the cross loadings of the indicators (Hair et al., 2013). For the discriminant validity, a component is considered reliable when its value is higher than 0.7 and the construct loading is higher than 
its cross loading. Table 3 above shows that almost all the indicators for the employed model's loadings are higher than 0.7, and thus are assumed reliable (Hair et al., 2013). Furthermore, according to Table 3, the cross-loadings of almost all the indicators' loadings are higher than the entire cross-loadings, confirming discriminant validity. For discriminant validity based on the Fornell-Larcker criterion, the AVE for each indicator should be higher than the construct's highest squared correlation to another construct. As observed in Table 2, all constructs, except for need for achievement and self-efficacy, meet the set criteria. However, since the AVE values as noted in Table 4 are higher than 0.5 and almost all loading of each indicator is found to be greater than all of its cross-loadings (Table 3), this study concludes that there is no evidence of a lack of discriminant validity.

Table 4 Demographic, Reliability, and Validity

\begin{tabular}{lcccccc}
\hline & Items & Mean & SD & $\begin{array}{c}\text { Cronbach's } \\
\text { Alpha }\end{array}$ & $\begin{array}{c}\text { Composite } \\
\text { Reliability }\end{array}$ & AVE \\
\hline Self-Improvement & 4 & 3.2013 & 1.11009 & 0.831 & 0.889 & 0.668 \\
Self-Confidence & 8 & 2.8013 & 1.11279 & 0.891 & 0.915 & 0.578 \\
Openness to Change & 3 & 2.9675 & 1.04657 & 0.863 & 0.916 & 0.785 \\
Pull Factors & 3 & 3.2038 & 1.09143 & 0.910 & 0.943 & 0.847 \\
Need for Achievement & 7 & 3.1525 & 1.01761 & 0.934 & 0.947 & 0.721 \\
Entrepreneurial Motivation & 25 & 2.38 & 1.053 & 0.965 & 0.968 & 0.551 \\
\hline
\end{tabular}

\subsection{Path Coefficients}

Path coefficients are estimated path relationships in the structural model (i.e., between the constructs in the model) (Hair et al., 2013). Table 5 below portrays that the path coefficients of Self-Improvement, Self-Confidence, Openness to Change, Pull Factors, and Need for Achievement have a positive and statistically significant (at the chosen 5\% level of significance) effect on Entrepreneurial Motivation indicating that the constructs employed are significantly able to predict Entrepreneurial Motivation. Furthermore, it could also be translated from the Beta and t-values of Table 5 that Need for Achievement as a single construct makes the strongest unique contribution in explaining Entrepreneurial Motivation as reflected by its highest Beta value and relatively high percentage variance explained, followed by Self-Confidence, Pull Factors, Self-Improvement, and Openness to Change.

Table 5 Path Coefficients of Reflective Hierarchical Model

\begin{tabular}{lccc}
\hline & Beta & $\boldsymbol{t}$-value & $\boldsymbol{p}$-value \\
\hline Self-Improvement $\rightarrow$ Entrepreneurial Motivation & 0.156 & 27.206 & 0.000 \\
Self-Confidence $\rightarrow$ Entrepreneurial Motivation & 0.320 & 70.192 & 0.000 \\
Openness to Change $\rightarrow$ Entrepreneurial Motivation & 0.133 & 39.160 & 0.000 \\
Pull Factors $\rightarrow$ Entrepreneurial Motivation & 0.157 & 53.317 & 0.000 \\
Need for Achievement $\rightarrow$ Entrepreneurial Motivation & 0.347 & 66.358 & 0.000 \\
\hline
\end{tabular}

\section{CONCLUSIONS AND RECOMMENDATION}

Previous researchers have criticized the existing empirical studies on the role of human motivators in entrepreneurship; however, recent entrepreneurship research (Shane et al., 2003) has argued that such criticisms have resulted in insufficient consideration of the otherwise significant role of motivation in the entrepreneurial process. Moreover, acknowledging the well-versed significance of entrepreneurial motivation among relevant theoretical models to predict entrepreneurial behavior and thereby influence firm performance (Robichaud et al., 2001), the present study felt it was necessary to develop a valid instrument to measure the construct, particularly in the context of entrepreneurship among low-income and underprivileged communities in a developing nation (Naude, 2010), which remains a 
significant and yet unexplored research area. Against such a backdrop, the present study attempts to answer the research call of Naude (2010) to explore the depths of entrepreneurship in the context of developing economies, and thereby examine Self-Improvement, SelfConfidence, Openness to Change, Pull Factors, and Need for Achievement as indicators and valid measures of Entrepreneurial Motivation.

While it is acknowledged that the findings of the present study are mere incremental contributions to the overall understanding and knowledge of entrepreneurial motivation; however, in its contribution, this study has forwarded and confirmed the reliability and validity of a new instrument to measure Entrepreneurial Motivation. As posited, the present study has found significant relationships between Entrepreneurial Motivation and all of its components (i.e., Self-Improvement, Self-Confidence, Openness to Change, Pull Factors, and Need for Achievement) by means of relevant statistical analyses. The instrument development and validation process for all constructs employed by the present study have confirmed that the new instrument to measure entrepreneurial motivation is not only internally consistent, but also multi-dimensional and stable across samples. It is therefore recommended that future researchers use the instrument forwarded by the present study and thereby carry out quantitative studies focused on entrepreneurial motivation.

Funding: This research was funded by the Ministry of Higher Education, Malaysia under the grant entitled "Developing a Comprehensive Rural Entrepreneurship Model for Poverty Eradication (REMODE)” (R/NRGS/A01.00/00047A/006/2014/000149).

\section{REFERENCES}

[1] Afthanorhan, A., Foziah, H., \& Majid, N. A. (2020). Investigating digital library success using the DeLone and McLean information system success 2.0: The analysis of common factor based structural equation modeling. Paper presented at the Journal of Physics: Conference Series, , 1529(4) doi:10.1088/1742-6596/1529/4/042052

[2] Al-Mamun, A., \& Ekpe, I. (2016). Entrepreneurial traits and micro-enterprise performance: A study among women micro-entrepreneurs in Malaysia. Development in Practice, 26(2), 193202.

[3] Al-Mamun, A., Saufi, R. A., \& Ismail, M. B. (2016). Human capital, credit, and startup motives: A study among rural micro-enterprises in Malaysia. The Journal of Developing Areas, 50(4), 383-400.

[4] Almobaireek, W., \& Manolova, T. (2012). Who wants to be an entrepreneur? Entrepreneurial intentions among Saudi university students. African Journal of Business Management, 6(11), 4029-4040.

[5] Bahkia, A. S., Awang, Z., Afthanorhan, A., Ghazali, P. L., \& Foziah, H. (2019, August). Exploratory factor analysis on occupational stress in context of Malaysian sewerage operations. In AIP Conference Proceedings (Vol. 2138, No. 1, p. 050006). AIP Publishing.

[6] Baistaman, J., Awang, Z., Afthanorhan, A., \& Rahim, M. Z. A. (2020). Developing and validating the measurement model for financial literacy construct using confirmatory factor analysis. Humanities and Social Sciences Reviews, 8(2), 413-422. doi:10.18510/hssr.2020.8247

[7] Bandura, A. (1997). Self-efficacy: The exercise of self control. New York: Freeman.

[8] Barba-Sánchez, V., \& Atienza-Sahuquillo, C. (2012). Entrepreneurial behavior: Impact of motivation factors on decision to create a new venture. Investigaciones Europeas de Dirección y Economía de la Empresa, 18(2), 132-138.

[9] Baum, R. (1994). The Relation of traits, competencies, vision, motivation, and strategy to venture growth. Unpublished doctoral dissertation, University of Maryland, College Park, MD.

[10] Baumol, W. J. (1996). Entrepreneurship: Productive, unproductive, and destructive. Journal of Business Venturing, 11(1), 3-22. 
Mohd Nor Hakimin B Yusoff, Fakhrul Anwar Zainol, Mohamad B Ismail, Abdullah Al-Mamun, Tengku Md Azizudin Tuan Mahmood, Asyraf Afthanorhan

[11] Beaugrand, P. (2004). And Schumpeter said, this is how thou shalt grow: Further quest for economic growth in poor countries. IMF Working Papers, 4(40), 1-21.

[12] Bin Yusoff, M. N. H., Zainol, F. A., \& Bin Ibrahim, M. D. (2015). Entrepreneurship education in Malaysia's public institutions of higher learning-A review of the current practices. International Education Studies, 8(1), 17-28.

[13] Carter, N. M., Gartner, W. B., Shaver, K. G., \& Gatewood, E. J. (2003). The career reasons of nascent entrepreneurs. Journal of Business Venturing, 18(1), 13-39.

[14] Collins, C., Locke, E., \& Hanges, P. (2000). The relationship of need for achievement to entrepreneurial behavior: A meta-analysis. Working paper, University of Maryland, College Park, MD.

[15] Daily, C. M., Patricia, P. M., Covin, J. G., \& Dalton, D. R. (2002). Governance and strategic leadership in entrepreneurial firms. Journal of Management, 28(3), 387-412.

[16] Eijdenberg, E. L., \& Masurel, E. (2013). Entrepreneurial motivation in a least developed country: Push factors and pull factors among MSEs in Uganda. Journal of Enterprising Culture, 21(1), 19-43.

[17] Grilo, I., \& Thurik, A. R. (2008). Determinants of entrepeneurial engagement levels in Europe and the US. Industrial and Corporate Change, 17(6), 1113-1145.

[18] Hair, J. F., Hult, G. T. M., Ringle, C., \& Sarstedt, M. (2013). A primer on partial least squares structural equation modeling (PLS-SEM). Sage Publications.

[19] Hair, J. F., Ringle, C. M., \& Sarstedt, M. (2011). PLS-SEM: Indeed a silver bullet. The Journal of Marketing Theory and Practice, 19(2), 139-152.

[20] Henseler, J., Ringle, C.M., \& Sinkovics, R. R. (2009), The use of partial least squares path modeling in international marketing. Advances in International Marketing, 20, 277-319.

[21] Hessels, J., Gelderen, M. V., \& Thurik, R. (2008). Entrepreneurial aspirations, motivations, and their drivers. Small Business Economics, 31(3), 323-339.

[22] Hussain, J. G., Scott, J. M., \& Hannon, P. D. (2008). The new generation: Characteristics and motivations of BME graduate entrepreneurs. Education \& Training, 50(7), 582-596.

[23] Johnson, B. (1990). Toward a multidimensional model of entrepreneurship: the case of achievement motivation and the entrepreneur. Entrepreneurship Theory and Practice, 14(3), $39-54$.

[24] Kiggundu, M. N. (2002). Entrepreneurs and entrepreneurship in Africa: What is known and what needs to be done. Journal of Developmental Entrepreneurship, 7(3), 239-258.

[25] Kirzner, I. (1997). Entrepreneurial discovery and the competitive market process: An Austrian approach. Journal of Economic Literature, 35(1), 60-85.

[26] Levesque, M., Shepherd, D. A., \& Douglas, E. J. (2002). Employment or self-employment? A dynamic utility-maximizing model. Journal of Business Venturing, 17(3), 189-210.

[27] Majid, N. A., Zainol, F. A., \& Afthanorhan, A. (2020). Does school cooperative program increase entrepreneurial intention? A structural equation modelling approach. Humanities and Social Sciences Reviews, 8(2), 645-651. doi:10.18510/hssr.2020.8272

[28] Majid, N. A., Zainol, F. A., Daud, W. N. W., \& Afthanorhan, A. (2019). Cooperative Entrepreneurship in Malaysian Secondary Schools: A Review of Current Practices. The Journal of Social Sciences Research, 5(3), 812-818.

[29] Man, T. W., Lau, T., \& Snape, E. (2008). Entrepreneurial competencies and the performance of small and medium enterprises: An investigation through a framework of competitiveness. Journal of Small Business \& Entrepreneurship, 21(3), 257-276.

[30] McClelland, D. C. (1961). The achieving society. Princeton, NJ: Van Nostrand.

[31] Mitchell, B. C. (2004). Motives for entrepreneurs: A case study of South Africa. Journal of Entrepreneurship, 13,(2), 167-183. 
[32] Mohamad, M., Afthanorhan, A., Awang, Z., \& Mohammad, M. (2019). Comparison Between CB-SEM and PLS-SEM: Testing and Confirming the Maqasid Syariah Quality of Life Measurement Model. The Journal of Social Sciences Research, 5(3), 608-614.

[33] Naude, W. (2010). Entrepreneurship, developing countries, and development economics: New approaches and insights. Small Business Economics, 34(1), 1-12.

[34] Naude, W., Gries, T., Wood, E., \& Meintjies, A. (2008). Regional determinants of entrepreneurial start-ups in a developing country. Entrepreneurship and Regional Development, 20(2), 111-124.

[35] Nazri, M. A., Aroosha, H., \& Omar, N. A. (2016). Examination of Factors Affecting Youths' Entrepreneurial Intention: A Cross-Sectional Study. Information Management and Business Review, 8(5), 14-24.

[36] Noraishah, B. (2003). Entrepreneurs psychometric index, available at http://www.piken.com.my (Accessed: 22 May, 2016)

[37] Norasmah, O. (2006). Indeks keusahawanan remaja malaysia, manual \& instrumen.

[38] Praag, C. M. V., \& Cramer, J. S. (2001). The roots of entrepreneurship and labor demand: individual ability and low risk. Economica, 68(269), 45-62.

[39] Renko, M., El-Tarabishy, A., Carsrud, A. L., \& Brännback, M. (2015). Understanding and measuring entrepreneurial leadership style. Journal of Small Business Management, 53(1), 5474.

[40] Rindova, V., Barry, D., \& Ketchen, D. (2009). Introduction to special topic forum: Entrepreneuring as emancipation. Academy of Management Review, 34(3), 477-491.

[41] Robichaud, Y., McGraw, E., \& Alain, R. (2001). Toward the development of a measuring instrument for entrepreneurial motivation. Journal of developmental entrepreneurship, 6(2), 189-201.

[42] Sabiu, I.T., Zainol, F.A., Abdullah, A.A (2019) Developing Entrepreneurship for Hausa People in Nigeria: The Paradox of Reality, International Journal of Innovation, Creativity And Change, pp. 193-208, ISSN: 22011323

[43] Saleh, A. S., \& Ndubisi, N. O. (2006). An evaluation of SME development in Malaysia. International Review of Business Research Papers, 2(1), 1-14.

[44] Shane, S., \& Venkataraman, S. (2000). The promise of entrepreneurship as a field of research. Academy of Management Review, 25(1), 217-226.

[45] Shane, S., Locke, E. A., \& Collins, C. J. (2003). Entrepreneurial motivation. Human Resource Management Review, 13(2), 257-279.

[46] Spencer, L., \& Spencer, S. (1993). Competence at work: Models for superior performance. New York: Wiley.

[47] Wanberg, C. R., \& Banas, J. T. (2000). Predictors and outcomes of openness to changes in a reorganizing workplace. Journal of applied Psychology, 85(1), 132-142.

[48] Yusof, W.N.H.S.W., Zainol, F.A., Daud, W.N.W (2019) Firm Level Self-efficacy: Are Graduates Ready To Be Entrepreneurs?, International Journal of Innovation, Creativity And Change, pp. 1-17, ISSN: 2201-1323

[49] Zahra, S., \& Dess, G. (2001). Entrepreneurship as a field of research: Encouraging dialogue and debate. Academy of Management Review, 26(1), 8-11.

[50] Zainol, R, N., Zainol., A., F., Ibrahim, Y., Afthanorhan, A. (2019). Scaling up social innovation for sustainability: The roles of social enterprise capabilities. Management Sciences Letters, 9(3), 1-10. 